\title{
Molecular detection of establishment and geographical distribution of Brazilian isolates of Neozygites tanajoae, a fungus pathogenic to cassava green mite, in Benin (West Africa)
}

\author{
Bonaventure V. Agboton • Rachid Hanna • Andreas von Tiedemann
}

Received: 25 January 2010/Accepted: 21 August 2010/Published online: 14 September 2010

(C) The Author(s) 2010. This article is published with open access at Springerlink.com

\begin{abstract}
Diagnostic PCR with two specific primer pairs (NEOSSU and 8DDC) were used to monitor the establishment and geographical distribution of Brazilian isolates of Neozygites tanajoae Delalibera, Hajek and Humber (Entomophthorales: Neozygitaceae) released in Benin for the biological control of the cassava green mite, Mononychellus tanajoa (Bondar) (Acari: Tetranychidae). A total of 141 cassava fields were visited and samples of $M$. tanajoa suspected to be infected by $N$. tanajoae were collected in 60 fields distributed between the coastal Southern Forest Mosaic (SFM) and the Northern Guinea Savanna (NGS) zones of Benin, West Africa. Analysis of DNA samples of dead mites using the species specific NEOSSU primers revealed the presence of $N$. tanajoae in 46 fields. The second country specific pair of primers 8DDC revealed the presence of Brazilian isolates of $N$. tanajoae in 36 fields, representing $78.3 \%$ of fields positive for $N$. tanajoae. Brazilian isolates occurred from SFM to NGS zones in Benin, however, they were concentrated in fields located within former release zones (e.g. Department of Ouémé in the South and Borgou in the North). In contrast, the indigenous African isolates of $N$. tanajoae were evenly distributed in the sub-humid and humid savannah zones of the country. The mean infection rate of $M$. tanajoa with indigenous isolates of $N$. tanajoae was relatively low (5.3\%) compared to Brazilian isolates (28\%), indicating a higher biocontrol potential of the latter. This first post-release monitoring using PCR techniques showed that the Brazilian strains of $N$. tanajoae is well established in Benin and spread effectively in this area.
\end{abstract}

Keywords Entomopathogenic fungi - Biocontrol · PCR techniques · NEOSSU and 8DDC primers $\cdot$ Neozygites tanajoae $\cdot$ Mononychellus tanajoae $\cdot$ Manihot esculenta

B. V. Agboton $(\bowtie) \cdot$ R. Hanna

International Institute of Tropical Agriculture, 08 BP 0932 Cotonou, Republic of Benin e-mail: bogboton@yahoo.fr

B. V. Agboton · A. von Tiedemann

Department of Crop Sciences, Division of Plant Pathology and Plant Protection, Georg-August University of Göttingen, Grisebachstr. 6, 37077 Göttingen, Germany 


\section{Introduction}

The cassava green mite (CGM), Mononychellus tanajoa (Bondar) (Acari: Tetranychidae), a native to South America was accidentally introduced into sub-Saharan Africa in the early 1970s causing significant reduction in crop yields (30-80\%) and threatening food security throughout much of the African cassava belt (Lyon 1973; Herren and Bennett 1984; Yaninek and Herren 1988). Numerous species of arthropod-pathogenic fungi are known to cause naturally-occurring epizootics that may decimate host population in the native region of cassava green mite.

Neozygites tanajoae Delalibera, Hajek and Humber (Entomophthorales: Neozygitaceae), one of the most efficient natural enemies of the CGM in Brazil (Delalibera 2002) was introduced into Benin (West Africa) in 1998/1999 for the biocontrol of cassava green mite. $N$. tanajoae is highly specific to CGM as it is not known to infect any other host (Delalibera et al. 2004; Agboton et al. 2009b). N. tanajoae isolates from Brazil are morphologically similar to mite pathogenic isolates in Africa and other countries in South America (Delalibera et al. 2004). Post-release monitoring conducted in an experimental field in Benin in 2000 revealed a highest infection rates on the plots with the Brazilian isolates compared with the indigenous ones (Hountondji et al. 2002).

Although observations from experimental release fields gave vague evidence of establishment and better performance of the Brazilian isolates, no reliable techniques were available for differentiating these isolates of $N$. tanajoae from the indigenous (African) ones among post-release field collections. Moreover, no post-release field studies were conducted to differentiate $N$. tanajoae isolates in the field and to monitor their effective establishment in West Africa.

Two specific pairs of oligonucleotide primers have been recently designed for PCR detection of $N$. tanajoae and the differential determination of the geographic origin of isolates of the fungus from Brazil and Africa. These primers have been evaluated for their suitability in identification and monitoring the Brazilian isolate of $N$. tanajoae on infested mites (Agboton et al. 2009a).

In the present study diagnostic PCR with NEOSSU and country specific primer 8DDC (Agboton et al. 2009a) were used to monitor the establishment and dispersal of Brazilian isolates of $N$. tanajoae that were released in cassava fields in Benin as biocontrol agents against $M$. tanajoa. This is the first major study on the occurrence, establishment and distribution of Brazilian isolates of $N$. tanajoae in the main cassava production areas in Benin as compared to indigenous isolates of the fungus. Information obtained by this study will be a key element for an appropriate post- release monitoring of $N$. tanajoae and improve follow-up strategies for the biocontrol of CGM in African cassava fields.

\section{Materials and methods}

Survey routes and sample collection

The surveys were conducted in January, April and July 2007 and covered ten of the twelve departments in Benin. During these surveys, a total of 141 cassava fields were visited. The survey routes were selected across the main cassava-growing areas to include as many cassava fields for sampling as possible. Along the routes, cassava fields were visited at intervals of $10-15 \mathrm{~km}$ in southern Benin, where cassava fields are more frequent. In the north, where cassava fields are sparser, sampling intervals were about 20 to $30 \mathrm{~km}$. 
Geographic latitude and longitude coordinates were recorded from each cassava field using a handheld Global Positioning System (GPS-Magellan 2000 XL) in order to map the distribution of $N$. tanajoae isolates in Benin. In each field, 30 plants were randomly selected and the first fully expanded leaf collected from each plant. The leaves were placed separately in a paper bag and incubated in an icebox (at about $8^{\circ} \mathrm{C}$ ) overnight for inducing the mummification process of accompanying mites. After the incubation, leaves were examined under the dissecting microscope. Dead mummified mites suspected to be infected with $N$. tanajoae were collected from the leaves and mounted on microscope slides in lactophenol Amman's blue stain and examined under a phase contrast microscope for the presence of pathogens. The numbers of living CGM and dead CGM infected by $N$. tanajoae were recorded. If mummified dead mites were found the field was considered colonized by $N$. tanajoae and sampled mites were collected from the leaves and stored at $4{ }^{\circ} \mathrm{C}$ in Eppendorf tubes $(2 \mathrm{ml})$ on dry cotton wool on top of silica gel. Rate of infection was calculated per field according to the number of leaves with presence of mites infected with the entomopathogenic fungus.

\section{Sample preparation and DNA extraction}

Ten random samples of dead mites from each of 60 sampled fields where $N$. tanajoae was suspected after the microscopic check were used for DNA extraction. From each field 10 mummified mites were placed each individually in a PCR plate well $(0.5 \mathrm{ml})$. Each sample was thoroughly submersed in $10 \mu \mathrm{l}$ of autoclaved distilled water. The PCR plate with the cadavers was covered with an adhesive sealing film and incubated at $25^{\circ} \mathrm{C}$ overnight. This allowed the cadavers to soften and the fungus to sporulate. In total, 600 samples of suspected mummified mites were prepared for DNA extraction. All the fields and locations from where isolates were sampled and analysed during this study are listed in detailed additional information file that is available upon request.

Genomic DNA was extracted using the InstaGene ${ }^{\mathrm{TM}}$ Matrix, Easy DNA kit (Bio-Rad Laboratories, Hercules, CA, USA), following the procedure described by the manufacturer for fungal DNA extraction. InstaGene ${ }^{\mathrm{TM}}$ Matrix $(50-100 \mu \mathrm{l})$ was added to each PCR tube $(0.5 \mathrm{ml})$. DNA was dissolved in $20-40 \mu \mathrm{l}$ of the resulting supernatant which was collected and stored at $-20^{\circ} \mathrm{C}$ until use. From each sampled field, 10 independent DNA samples were prepared from ten different infected mites. However, per field we run PCR with those 10 independent samples and once one of those 10 revealed positive with 8DDC, we targeted the particular field positive to Brazilian.

PCR analysis of field samples

DNA samples extracted from the field collections were checked by PCR using at first NEOSSU_F/NEOSSU_R primers for $N$. tanajoae species detection followed by 8DDC_F/ 8DDC_R for Brazilian isolates identification. Each DNA sample was examined with PCR using separately the two primer pairs. PCR amplification was performed in a PTC-100 thermocycler (MJ Research) in a $25-\mu$ l volume containing specific primers $(0.4 \mu \mathrm{l})$, Promega Master Mix $(12.5 \mu \mathrm{l})$, nuclease-free water $(10.1 \mu \mathrm{l})$ and $2 \mu \mathrm{l}$ of DNA sample. Sterile deionised water and DNA extracted from uninfected cassava green mite cadavers were used as negative controls. Amplification was performed using the following conditions: initial denaturation at $94^{\circ} \mathrm{C}$ for $4 \mathrm{~min}, 38$ cycles of denaturation at $94^{\circ} \mathrm{C}$ for $1 \mathrm{~min}$, annealing at $52^{\circ} \mathrm{C}$ for $1 \mathrm{~min} 30 \mathrm{~s}$ and extension at $72^{\circ} \mathrm{C}$ for $2 \mathrm{~min} 30 \mathrm{~s}$, final extension at $72^{\circ} \mathrm{C}$ for $5 \mathrm{~min}$, cool down at $8^{\circ} \mathrm{C}$ and storing of the PCR product at $-20^{\circ} \mathrm{C}$ until use. To 
visualize the DNA amplicons, $10 \mu \mathrm{l}$ of the PCR products from each isolate was loaded on a gel containing $1.5 \%$ agarose in $0.5 \times \mathrm{TBE}$ buffer. Gels were run for $1 \mathrm{~h}$ at $3 \mathrm{Volt} / \mathrm{cm}$, stained with ethidium bromide, visualized with UV light and photographed. GeneRulerTM100 bp ladder Plus was used as DNA size marker and consistently amplified bands were scored for data analysis. All reaction components except for the primers were purchased from MBI Fermentas (St. Leon Roth, Germany).

Data analysis and isolate mapping

Proportions of infected mites were normalized by arcsine-transformation and used to estimate the rate of infection. Average numbers of mites and percent infection were obtained using PROC MEANS of SAS software (SAS Institute 2007, Cary, NC, USA). Mapping of the distribution of $N$. tanajoae and mainly Brazilian isolates within Benin was done with ARC-VIEW software associated with African boundary data using the corresponding GPS coordinates.

\section{Results}

Survey on distribution of Neozygites tanajoae

The survey covered the whole country of Benin except for the Sudan Savannah Zone where cassava is not produced. Within the 10 provinces covered, a total of 141 cassava fields were surveyed, ranging from the coastal Southern Forest Mosaic (SFM) to the Northern Guinea Savannah (NGS) vegetation zones (Fig. 1, Table 1). Out of the 141 cassava fields surveyed, mite samples suspected of $N$. tanajoae infection were found and collected in 60 cassava fields representing 9 departments in the SFM and NGS agro-ecological zones, except Atacora (Table 1 and 2). However, infection rates of $M$. tanajoa by the fungus were not uniform across the surveyed fields. In some fields infection rates were low (1\%) while in other fields it exceeded $97 \%$. The highest infection rates were observed in the departments of Mono, Ouémé, Collines and Borgou, with 95.6, 96.7, 78.6 and 89.7\%, respectively (detailed information is available upon request). The first two departments where the infection rates were the highest are located in the SFM zones and the other two are found in the NGS zones (Fig. 1).

Molecular detection of Neozygites tanajoae of native and Brazilian origin

Samples yielding $800 \mathrm{bp}$ amplicons following PCR with NEOSSU primers were considered positive for $N$. tanajoae infection while those amplified with the 8DDC primers producing amplicoms of $600 \mathrm{bp}$ were considered positive for Brazilian species of N. tanajoae (Table 1).

Out of 60 fields sampled, suspected containing N.tanajoae, 46 were positive for the presence of $N$. tanajoae indicated by amplicons of 800 bp (Fig. 2; A1, B1, C1, D1). Samples from the remaining 14 fields were not amplified by the NEOSSU primers, indicating a lack of $N$. tanajoae in those fields (Fig. 2; A1, B1, C1, D1).

Further investigations of the DNA samples from the 46 fields testing positive for $N$. tanajoae with the 8DDC primers showed the presence of the Brazilian isolate of $N$. tanajoae in 36 fields (Table 1; Fig. 2; A2, B2, C2, D2). Thus, the double amplification 


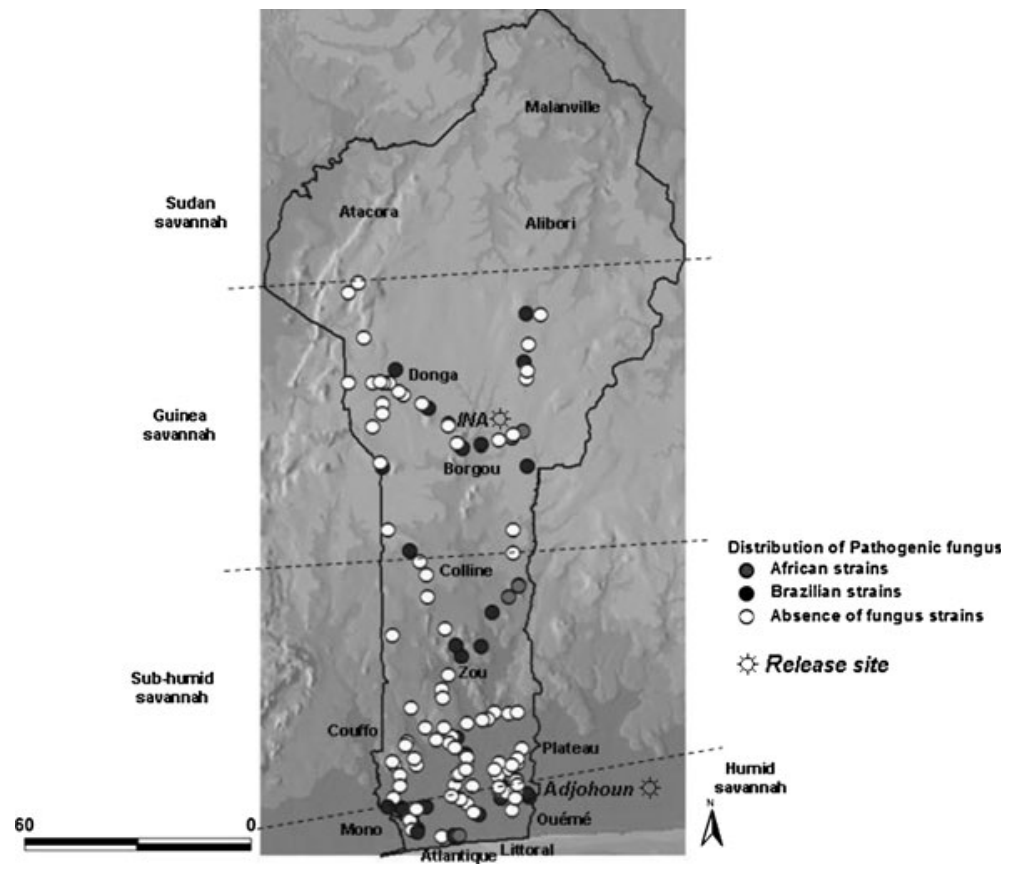

Fig. 1 Distribution of African and Brazilian isolates of Neozygites tanajoae associated with cassava green mite in different agroecological zones of Benin. Agroecological zones, departments, former release points, surveyed field sites and sample identification are indicated (scale bar gives distances in $\mathrm{km}$ )

Table 1 Neozygites tanajoae infection rates of CGM (Mononychellus tanajoa) within cassava fields in Benin related to the presence of Brazilian isolates detected by species-specific primers (NEOSSU) and differentiated by country specific primers $(8 \mathrm{DDC})$; the detailed information is available upon request

\begin{tabular}{llll}
\hline & Number & Percentage & Types of N. tanajoae \\
\hline Surveyed fields & 141 & - & - \\
Sampled fields & 60 & 42.5 of visited fields & Presence and absence \\
Fields with $N$. tanajoae & 46 & 76.7 of sampled fields & Mix isolates \\
$\begin{array}{l}\text { Amplicons with NEOSSU } \\
\quad 36 \text { 8Dd }\end{array}$ & 36 & 78.3 of fields with $N$. tanajoae & Brazilian isolates \\
Amplicons with NEOSSU only & 10 & 21.7 of fields with $N$. tanajoae & African isolates \\
\hline
\end{tabular}

generated by NEOSSU and 8DDC primers (Table 1; Fig. 2) enabled the detection and differentiation of Brazilian strains of $N$. tanajoae on real field samples (Agboton et al. 2009a). In conclusion, 36 fields tested positive for Brazilian isolates representing $78.3 \%$ of all fields where $N$. tanajoae was detected (Table 1).

The number of fields with presence of $N$. tanajoae was high in Mono, Oueme, Colline and Borgou (7 fields at least), while in the other departments the highest number of positive fields was 4 (amplification with NEOSSU; Table 2). Overall, the 46 fields tested positive for the presence of $N$. tanajoae represented $76.7 \%$ of the 60 fields sampled for PCR investigation. 
Table 2 PCR results on samples collected from 60 fields in different Departments of Benin in 2007, identified by PCR using NEOSSU and 8DDC primers

\begin{tabular}{|c|c|c|c|c|c|c|}
\hline \multirow[t]{2}{*}{ Department } & \multirow{2}{*}{$\begin{array}{l}\text { No. of } \\
\text { fields } \\
\text { surveyed }\end{array}$} & \multirow{2}{*}{$\begin{array}{l}\text { No. of } \\
\text { sampled } \\
\text { fields* }\end{array}$} & \multicolumn{2}{|c|}{ No. of fields with amplicons for } & \multirow{2}{*}{$\begin{array}{l}\text { Percentage of } \\
\text { fields with } \\
\text { infected mites** }\end{array}$} & \multirow{2}{*}{$\begin{array}{l}\text { Percentage of } \\
\text { fields with Brazilian } \\
\text { isolates** }\end{array}$} \\
\hline & & & NEOSSU & 8DDC & & \\
\hline Couffo & 10 & 2 & 2 & 1 & 20.0 & 10.0 \\
\hline Mono & 17 & 11 & 10 & 7 & 58.8 & 41.2 \\
\hline Atlantique & 15 & 7 & 4 & 3 & 26.7 & 20.0 \\
\hline Ouémé & 16 & 9 & 8 & 7 & 50.0 & 43.8 \\
\hline Plateau & 17 & 5 & 3 & 3 & 17.7 & 17.7 \\
\hline Zou & 16 & 5 & 2 & 2 & 12.5 & 12.5 \\
\hline Colline & 15 & 9 & 8 & 6 & 53.3 & 40.0 \\
\hline Borgou & 15 & 9 & 7 & 5 & 46.7 & 33.3 \\
\hline Dongo & 17 & 3 & 2 & 2 & 11.8 & 11.8 \\
\hline Atacora & 3 & 0 & 0 & 0 & 0.0 & 0.0 \\
\hline Total & 141 & 60 & 46 & 36 & & \\
\hline
\end{tabular}

* Number of fields sampled per department (fields selected following microscopic check of mite infection; 10 independent samples were taken from each field and assayed with PCR)

** Percentage of fields with presence of African or Brazilian isolates per department compared to the total number of surveyed fields
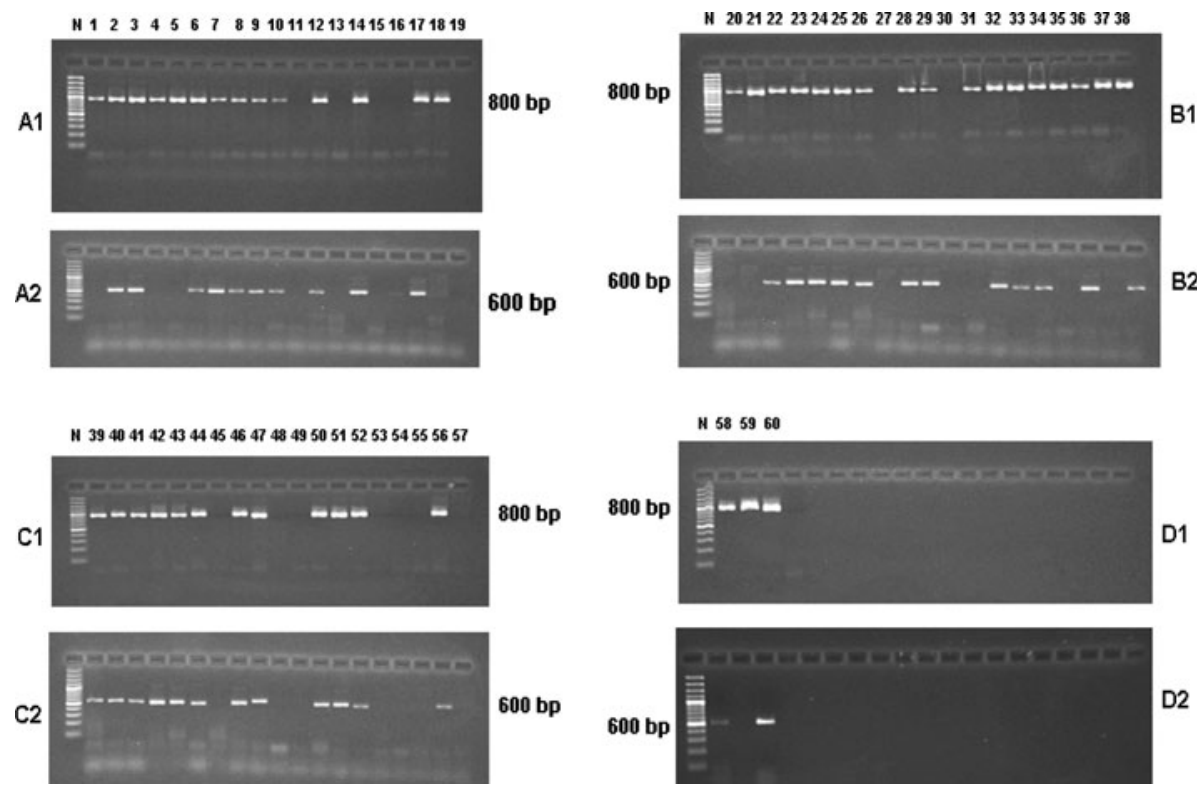

Fig. 2 PCR-based detection of Neozygites tanajoae by species-specific oligonucleotide primer pair NEOSSU_F/NEOSSU_R (A1, B1, C1 and D1). A1, B1, C1 and D1 show the species-specific amplicon of $800 \mathrm{bp}$. With primer pair 8DDC_F/8DDC_R specific to the Brazilian isolates, A2, B2, C2 and D2 show amplicons of $600 \mathrm{bp}$ indicating fields with presence of the exotic isolates. GeneRuler DNA ladder Mix (MBI Fermentas) is included in marker lane $\mathrm{N}$ (fragment sizes are indicated in bp). The negative control represents the absence of band (not shown in Fig. 2) 
Geographic distribution of Brazilian isolates in Benin

The 36 fields with presence of Brazilian isolates of $N$. tanajoae were distributed from the SFM zone to the NGS zones and concentrated around the former release points (Table 2; Fig. 1). Brazilian isolates of $N$. tanajoae were present in 9 out of the 10 departments surveyed, none was observed in the Atacora department (Table 2). The number of fields with presence of Brazilian isolates was higher in Mono, Ouémé, Collines and Borgou departments compared to the other departments (Table 2). In fact, the Brazilians strains were more present throughout the humid and seasonally moist agro-ecological zones of the cassava growing regions in Benin than in the drier zones (Fig. 1). Moreover, a significant correlation was obtained between the rate of CGM infection with the entomopathogen and the prevalence of Brazilian isolates in cassava fields $\left(P<0.01\right.$ and $\left.R^{2}=0.755\right)$ (Fig. 3).

\section{Discussion}

The results presented here provide the evidence of the establishment and dispersal in Benin of Brazilian strains of $N$. tanajoae found associated with the cassava green mite upon PCR amplification with specific primers. Our results also showed that the PCR assay with specific markers is sensitive enough to detect the infection of cassava green mites by $N$. tanajoae as sampled from commercial cassava fields. According to the previous finding, the detection and identification of DNA samples with PCR using specific primer pairs demonstrates that Brazilian and African isolates of $N$. tanajoae are genetically diverse, although morphologically similarity can be now separated by molecular techniques (Agboton et al. 2009a). A similar molecular approach has been used by Nakabonge et al. (2006) on different pathogens of Chrysoporthe spp. to follow their distribution in Eastern and Southern Africa. Indeed, PCR-based techniques have become widely used for the detection of plant pathogens (Gachon et al. 2004; Lievens and Thomma 2005; McCartney et al. 2003) as well as herbivore pathogens (Baek et al. 1998; Tigano et al. 2006; Peres et al. 2006).

With the aid of molecular detection methods the present study provides a first insight into distribution in Benin of the most important entomopathogen of Mononychellus tanajoa

Fig. 3 Infection rate of cassava green mite populations with Neozygites tanajoae in cassava fields in Benin as related to the prevalence of Brazilian isolates of the entomopathogenic fungus. Error bars on the graph show how data are spread with confidence intervals

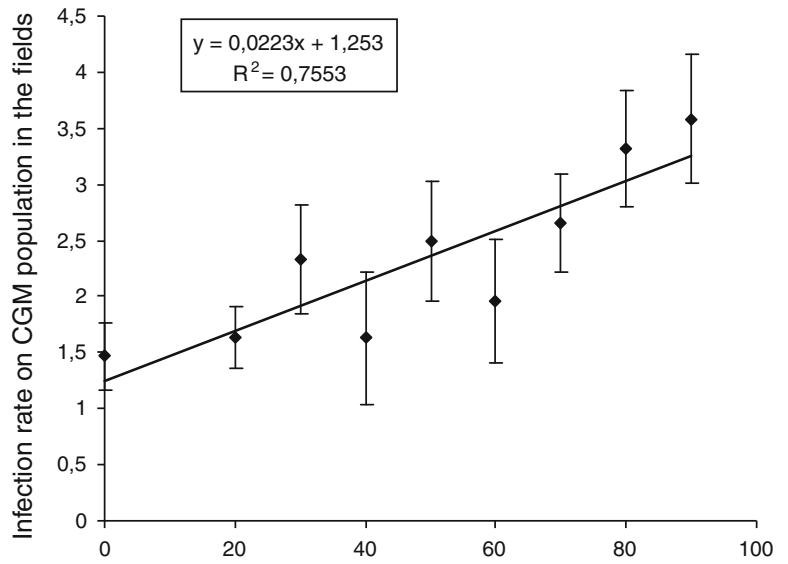

Percentage of Brazilian isolates of $N$. tanajoae in cassava fields 
currently known. This is the first time that molecular markers were used for monitoring the status of $N$. tanajoae dispersal in Benin, where the Brazilian isolates have been released in 1999. Our PCR results showed that $N$. tanajoae was present in 46 out of 60 fields proving that the fungus has reached a wide geographic distribution in Benin. The absence of $N$. tanajoae in the Department of Atacora may be due to the relatively short rainy season, a dryer season and the scarcity of cassava fields in this department (Yaninek et al. 1991). While $N$. tanajoae was present in nine provinces, its occurrence on CGM was not homogenous among all sampled fields. This finding is similar to that of Yaninek et al. (1996), suggesting that certain locations may be more favourable for the establishment and survival of the pathogen (Larsen et al. 2007) and infection of CGM. Moreover, the number of cassava fields associated with $N$. tanajoae was higher in the south where the agroecological conditions are more favourable for cassava production.

After having been released in Benin in January 1999 to control CGM (Hountondji et al. 2002), the main constraint to follow establishment and dispersal of the Brazilian isolates of $N$. tanajoae was the lack of reliable tools of detection and distinguishing them from the indigenous African strains. In the present field evaluation the molecular markers developed and tested in our previous work confirmed their potential to solve this problem. The results presented here provide the first molecular detection of Brazilian isolates of $N$. tanajoae released in commercial cassava fields in Benin.

The present results reveal the successful establishment and dispersal of Brazilian isolates throughout the seasonally humid ecological zones of the cassava agro-ecosystems in Benin. According to Yaninek et al. (1996) the annual precipitation is generally greater in southern than northern Benin that could enhance the fungal growth and may explain the higher infection rates found in southern Benin. Oduor et al. (1995) demonstrated that the determining factors of an epizooty are the climatic conditions (temperature, humidity) governing infection of mites and the fungus survival. In Brazilian conditions, nearly $100 \%$ of the adult female population of CGM has been shown to be infected with $N$. tanajoae depending on mite density, location, season and climate (Delalibera et al. 1992).

The rate of $78.3 \%$ of Brazilian isolates recorded from samples infested with $N$. tanajoae in Benin provides evidence for the effective establishment and dispersal of those isolates in Africa, mainly in Benin. Most cassava fields with Brazilian isolates present were found around the former release regions in northern and southern Benin, however, 9 years after the release of exotic isolates in only two departments, Ouémé (Adjohoun) and Borgou (Ina) in Benin, Brazilian isolates of $N$. tanajoae have spread to other 7 departments. The presence of the Brazilian isolates in those additional departments may be due to favourable environmental conditions they found in those different regions in Benin.

Interestingly, overall infection rates of CGM were significantly correlated with the prevalence of Brazilian isolates in cassava fields indicating a stronger biocontrol potential of the exotic pathogen strains to the suppression of CGM populations. This is in contrast to laboratory studies that showed very little or no difference in virulence between the local African isolates of N. tanajoae and the introduced Brazilian isolates (Dara et al. 1998a). Additional studies on the specific biopotential of indigenous and exotic entomopathogenic strains on common CGM and their relatedness to environmental conditions in the cassava growing areas in Africa are required to further improve implementation and management of this biocontrol strategy in practical use.

Acknowledgments We are grateful to the Deutscher Akademischer Austauschdienst (DAAD), the International Institute of Tropical Agriculture (IITA), for a field work grant from the International Fund for Agricultural Development (IFAD), and the University of Göttingen in Germany for supporting this research. 
Thanks are due to Italo Delalibera Jr, Birger Koopmann, Alexis Onzo, and Ignace Zannou for their advices on the work and their comments on an earlier version of the manuscript.

Open Access This article is distributed under the terms of the Creative Commons Attribution Noncommercial License which permits any noncommercial use, distribution, and reproduction in any medium, provided the original author(s) and source are credited.

\section{References}

Agboton VB, Delalibera I Jr, Hanna R, von Tiedemann A (2009a) Molecular detection and differentiation of Brazilian and African strains of the entomopathogen Neozygites tanajoae (Entomophthorales: Neozygitaceae) with PCR using specific primers. Biocont Sc Tech 19:67-79

Agboton VB, Hanna R, Hountondji FCC, von Tiedemann A (2009b) Pathogenicity and host specificity of Brazilian and African isolates of the acaropathogenic fungus Neozygites tanajoae to mite species associated with cassava. J App Entomol. doi: 10.1111/j.1349-0418.2009.01415.x

Baek SCMD, Chae HJMD, Dong HMD, Byun DGMD, Cho BKMD (1998) Detection and differentiation of causative fungi of onychomycosis using PCR amplification and restriction enzyme analysis. Internat J Derm 37:682-686

Dara SK, Lomer CJ, Hountondji FCC, Yaninek JS (1998a) Fungal pathogens of mites on cassava: field and laboratory studies. VIIth International Colloquium on Invertebrate Pathology and Microbial Control (abstract), Sapporo, Japan

Delalibera JrI (2002) Investigations towards implementation of Neozygites tanajoae sp. nov. as a classical biological control agent against the cassava green mite in Africa. PhD. Thesis, Cornell University, Ithaca, New York, pp 141

Delalibera I Jr, Sosa Gomez DR, de-Moraes GJ, Alentar JA, Farias de, Araujo W (1992) Infection of Mononychellus tanajoa (Acari: Tetranychidae) by the fungus Neozygites sp. (Entomophthorales) in Northeastern Brazil. Florida Entomol 75:145-147

Delalibera I Jr, Hajek AE, Humber RA (2004) Neozygites tanajoae sp. nov, a pathogen of the cassava green mite. Mycologia 96:1002-1009

Gachon C, Mingam A, Charrier B (2004) Real-time PCR: what relevance to plant studies? J Exp Bot 55:1445-1454

Herren HR, Bennett FD (1984) Cassava pests, their spread and control. In: advancing agricultural production in Africa, Arusha. Tanzania. Common Agricultural Bureau, Slough, UK

Hountondji FCC, Lomer CJ, Hanna R, Cherry AJ, Dara SK (2002) Field evaluation of Brazilian isolates of Neozygites floridana (Entomophthorales: Neozygitaceae) for the microbial control of cassava green mite in Benin, West Africa. Biocont Sc Tech 12:361-370

Larsen JE, Hollingsworth CR, Flor J, Dornbusch MR, Simpson NL, Samac DA (2007) Distribution of Phoma sclerotioides on alfalfa and winter wheat crops in the North Central United States. Pl Dis 91:551-558

Lievens B, Thomma BPHJ (2005) Recent developments in pathogen detection arrays: implications for fungal plant pathogens and use in practice. Phytopath 95:1374-1380

Lyon WF (1973) A plant-feeding mite Mononychellus tanajoa Bondar (Acarina: Tetranychidae) new to the African continent threatens cassava (Manihot esculenta Crantz) in Uganda, East Africa. Pest Artic News Summ 19:36-37

McCartney HA, Foster SJ, Fraaije BA, Ward E (2003) Molecular diagnostics for fungal plant pathogens. Pest Manag Sci 59:129-142

Nakabonge G, Roux J, Gryzenhout M, Wingfield MJ (2006) Distribution of Chrysoporthe canker pathogens on Eucalyptus and Syzygium spp.in eastern and southern Africa. Pl Dis 90:734-740

Oduor GI, Yaninek JS, van der Geest LPS, de-Moraes GJ (1995) Survival of Neozygites cf. floridana (Zygomycetes: Entomophthorales) in mummified cassava green mites and the viability of its primary conidia. Exp Appl Acarol 19:479-488

Peres NA, Harakava R, Carroll GC, Adaskaveg JE, Timmer LW (2006) Comparison of molecular procedures for detection and identification of Guignardia citricarpa and G. mangiferae. Pl Dis 91:525-531

SAS Institute (2007) SAS system for windows, statistics. release 6.12, version 9.1. SAS Institute Inc, Cary. $\mathrm{NC}$, USA

Tigano MS, Adams B, Maimala S, Boucias D (2006) Genetic diversity of Hirsutella thompsonii isolates from Thailan AFLP analysis and partial $\beta$-tubulin gene sequences. Genet Mol Biol. doi: 10.1590/ S1415-47572006000400022 
Yaninek JS, Herren HR (1988) Introduction and spread of the cassava green mite, Mononychellus tanajoa (Bondar) (Acari: Tetranychidae), an exotic pest in Africa and the search for appropriate control methods: a review. Bull Entomol Res 78:1-13

Yaninek JS, Baumgaertner J, Gutierrez AP (1991) Sampling the cassava green mite, Mononychellus tanajoa (Bondar), in Africa. Bull Entomol Res 81:201-208

Yaninek JS, Saizonou S, Onzo A, Zannou I, Gnanvossou D (1996) Seasonal and habitat variability in the fungal pathogens: Neozygites cf. floridana and Hirsutella thompsonii, associated with cassava mites in Benin. Biocont Sc Tech 6:23-33 